\title{
Impeding lone-wolf attacks: lessons derived from the 2011 Norway attacks
}

Sunniva Meyer

\begin{abstract}
Lone-wolf terrorism is often more difficult to detect through intelligence due to limited communication between plotters. This study addresses this problem by spelling out an alternative method for impeding such attacks. It combines crime scripts, situational crime prevention and rational planning to study how to impede attacks such as the 2011 Norway attacks. Analyzing the transport issues in these attacks demonstrates that some sort of entry control and measures facilitating the evacuation in case of prolonged attacks might reduce the harm.
\end{abstract}

Keywords: Lone-wolf attacks; Situational crime prevention; Crime scripts; Rational planning; Terrorism

\section{Background}

"Not even the DDR during the years of the Stasi, which we do not want to compare us with, could have stopped him"a Janne Kristiansen told the Norwegian newspaper, Dagbladet, after the 2011 Norway attacks. The offender, Anders Behring Breivik (ABB), had lived an apparently law-abiding life, and avoided voicing violent opinions to others (Klungtveit 2011, p. 16). And even if ABB left some tracks that could (and perhaps should) have warned the intelligence services of his plans (NOU 2012), his lone-wolf status made him more difficult to detect by intelligence alone. A lone-wolf terrorist operates individually, does not belong to an organized group or network and conceives and directs the modus operandi without any direct outside command or hierarchy (Spaaji 2012, p. 16). ABB was explicit about the political motivation behind his attacks, but even if we attempt to look for evidence of some kind of extremist ideas, not all lone-wolf attackers exhibit signs of any political purpose (Borum 2013), as such lone attacks may not fit the terrorism label.

This study aims to determine what sort of measures could obstruct lone-wolf attacks, either by stopping an attack entirely or simply reducing the harm inflicted. The author attempts to answer this problem by investigating the 2011 Norway attacks, because they demonstrate how much harm a resourceful and highly committed

Correspondence: sfm@toi.no

Department of Safety, Security and Environment, Institute of Transport Economics, Oslo NO-0349, Norway

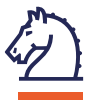

attacker can inflict alone. The individual attacks carried out by $\mathrm{ABB}$ are similar in that they were committed by the same offender on the same day, but differ in that the offender employed two different conventional weapons: improvised explosives and small arms. The paper primarily focuses on transport issues due to space limitations.

Most, if not all, of the measures discussed in this paper will of course also apply to other malicious plots that failed to be detected.

Lone-wolf terrorism is a marginal phenomenon compared to mainstream terrorism; Spaaji (2012), p. 27 demonstrates that among the terrorist incidents in his study, only $1.8 \%$ can be attributed to lone wolves. Among these lone-wolf incidents, $17 \%$ are motivated by right-wing extremism/white supremacy (Spaaji 2012, p. 37). Nesser (2012) has further shown that despite al-Qaida's efforts to ignite leaderless jihad in the West, very few jihadist terrorists in Europe have been true loners. None of the attackers in the 10 individual operations in Nesser's chronology of jihadist terrorist plots in Western Europe qualifies as a "lone wolf" in a strict sense since all the attackers seem to have some sort of link to organized radical environments (Nesser 2012). Despite lone-wolf terrorism's rarity, the 2011 Norway attacks have demonstrated how effective a lone-wolf attack can be, and Breivik's compendium (Berwick 2011) can be employed as an operational manual for future lone wolfs.

Despite the difficulties some scholars have attempted to establish what distinguishes lone wolves from other 
extremist offenders. Comparing far-right loners with other far-right homicide offenders, Gruenewald et al. (2013) have found that far-right loners are more likely to have a military background, less likely to be married and more likely to live completely alone. Phillips (2011), Phillips and Pohl (2012) and Phillips (2009) have all employed economic frameworks to establish how lone attackers would act if maximizing their utility. Lone wolves are expected to predominantly choose assassination ${ }^{\mathrm{b}}$, armed attack, bombing, hostage taking or unconventional attacks, rather than arson, hijacking or kidnapping (Phillips 2011). Phillips and Pohl (2012) used "economic profiling" to distinguish between risk-seeking and riskaverse lone wolves, while Phillips (2009) employed modern portfolio theory to show that that risk-averse terrorist groups should tend to exhibit a bias towards bombing and armed attack.

Since early detection is more difficult, a focus on the more immediate surroundings of the offence could prove to be more fruitful in advising authorities on how to respond to these attacks. Scholars have successfully employed environmental criminology, i.e. Situational Crime Prevention (SCP) theory, to suggest measures against "new crimes" such as identity theft, cyber crime, organized crime and illegal immigration (Freilich and Newman 2009), as well as terrorism. Moreover, Clarke and Newman (2006) have employed situational crime prevention to help identify the four basic pillars of terrorist action: distinguishing between targets, weapons, tools and the facilitating conditions. Meyer (2011) combined rational choice theory, SCP and crime scripts, and demonstrated that when protecting railways against explosive attacks, the authorities should prioritize measures that help reduce the impact of an explosive attack, rather than the probability that such an attack will succeed. Yun (2009) employed SCP and script theory in a case study of hostage taking in Afghanistan, concluding that: (1) the authorities need to deny the hostage takers gains through negotiation, and (2) the launching of military or law enforcement operations to disrupt the hostage situation might deter future hostage takers (Yun 2009). Freilich and Chermak (2009) apply SCP to two case studies of fatal far-right attacks against law enforcement in the United States, and suggest the use of "soft" measures that reduce provocations, such as avoiding threatening police behaviour. Belli and Freilich (2009) also propose employing a "soft" approach for preventing ideologically motivated tax refusals, including SCP measures such as reducing frustration and stress by simplifying the filing procedure.

All the scholars above have shown how environmental criminology can be employed to establish which measures should be employed against a wide range of crimes, including terror attacks. And when traditional intelligence fails in stopping lone wolves' pre-events, environmental criminology can still be used to deal with such attacks. This study aims to demonstrate this by outlining a method, combining crime scripts, situational crime prevention and rational planning for finding measures that may impede lone-wolf attacks and employing this method on the 2011 Norway attacks. More specifically, the study describes what sort of measures might have impeded the transport in the 2011 Norway attacks, and discusses whether these measures would also have impeded other comparable attacks.

Section 2 outlines methods and theories employed in this study. Section 3 first investigates what sort of measures might have stopped and/or reduced the harm from ABB's attack with a vehicle-borne explosive, and examines whether these measures also would have stopped and/or reduced the harm from comparable attacks. This exercise is repeated for ABB's shooting massacre at Utøya, and Section 4 draws conclusions.

\section{Methods}

This paper investigates the 2011 Norway attacks. It also discusses comparable solo attacks that have inflicted a lot of harm: to ensure diversity, cases where the political motivation were jihadists (one bombing and one shooting) and cases in which the motivation was right-wing (one bombing and one shooting) have been included: The 1995 Oklahoma City bombing (Hartzler 1997), the 2005 Doha Players Theatre bombing (Lepeska 2010; BBC News 2005b), the 1994 Tombs of the Patriarchs massacre (Church et al. 1994) and the 2009 Fort Hood shooting (NYTimes.com 2011). Lastly, a case similar to the Norway strike, but one that was foiled by the police is also discussed. This was the case of Brunon Kwiecien, a chemistry professor, who allegedly planned to attack the Polish parliament and was arrested in 2012 (West 2012).

The dependent variable in this study is the harm imposed, and attacks in which the offender succeeded in imposing a lot of harm have been deliberately chosen. This choice could bias the results and reduce the extent to which they can be generalised to less harmful attacks. However, measures that aim to impede more harmful attacks will, ceteris paribus, also be more effective than measures that aim at impeding less harmful attacks. The bias towards harmful solo attacks in this study is therefore beneficial rather than detrimental.

\section{The procedure}

The procedure consists of six steps: (1) identifying a crime script, (2) sketching a detailed narrative, (3) identifying script clashes, (4) identifying situational crime prevention measures, (5) indicating rational planning, and (6) discussing comparable attacks. 
First, "crime script(s)" are identified (1). A crime script is a description of the procedural sequence a criminal goes through when committing a specific type of crime. By spelling out the actions (and their goals) necessary to complete the crime, the crime script can "enhance situational crime prevention policies by drawing attention to a fuller range of possible intervention points" (Cornish 1994, pp. 159-160). The crime scripts in this paper are based upon both how ABB committed his attacks (open sources) and the author's impression of possible alternative actions in case he had faced other conditions or had chosen to act differently.

Second, what George and Bennett call a detailed narrative is sketched (2). The detailed narrative, or story, is presented in the form of a chronicle that purports to show how the attacks came about (George and Bennett 2005, p. 210).

Third, "script clashes", in which the offender's script engages with the user or preventer's script, are identified (3), including issues such as surveillance versus concealment, challenge versus excuse and pursuit versus escape (Ekblom 2011, p. 151).

Fourth, the information collected through the first three steps is employed to identify situational crime prevention measures that could have impeded the attack (4). Situational crime prevention focuses "on specific crime types, seeking to change the immediate environment such that potential offenders either are physically prevented from committing the crime or perceive the opportunities as limited and the risk as high, and thus might choose against committing the crime" (Clarke 1983, p. 225).

Fifth, how the offender might have reacted if faced with these measures is discussed (5). Would he have abandoned the attack entirely, gone through with the attack as planned (with a heightened risk of being prevented or less harm inflicted) or changed the attack significantly? Here, the rational choice approach is employed to speculate upon his optimal adaptations given different constraints. This perspective is referred to as rational planning, a natural extension of situational crime prevention theory.

Sixth, a discussion on whether the above measures would also have impeded comparable attacks, and two bombing and two shootings are included (6). As when choosing the primary attacks, solo attacks that inflicted a lot of harm have been selected. To ensure diversity, cases in which the political motivation was jihadists (one bombing and one shooting) and cases in which the motivation was right-wing (one bombing and one shooting) have been included.

On 19 April 1995, Timothy McVeigh planted a vehicle bomb in Oklahoma City, killing 168 people and injuring hundreds (Hartzler 1997). He is often given as a classic example of the "lone wolf", despite evidently having received extensive help prior to the day of the bombing, especially from Terry Nichols (Fattah 2007). The Oklahoma bombing has been included because it is the deadliest right-wing bomb attack since World War II.

On 19 March 2005, an Egyptian named Omar Ahmad Abdullah Ali detonated a car bomb at the Doha Players Theatre in Qatar, killing a British director and injuring 12 others; police believe he acted alone (Lepeska 2010; BBC news 2005b). The Doha Players Theatre bombing has been chosen because it is the deadliest jihadist lonewolf bombing attack since World War II.

On 25 February 1994, an Israeli settler opened fire on unarmed Muslims while they were praying at the Tombs of the Patriarchs (Church et al. 1994), killing 29 and injuring 125 worshipers in the shooting (Issacharoff and Levinson 2010). The Cave of the Patriarchs massacre has been included because it is the deadliest shooting massacre committed by a right-wing lone wolf, with the exception of the shooting massacre by ABB.

On 5 November 2009, an U.S. Army Major started shooting in Fort Hood, killing 13 people and hurting nearly 30 others (NYTimes.com 2011). This shooting massacre has been chosen because it is the deadliest shooting massacre committed by a jihadist lone wolf.

Lastly, a case designed to be similar to the Norway strike, but one that was foiled by the police, has been included. This case has been chosen because the attacker was both a self-proclaimed supporter of Breivik and the plot tactically resembled Breivik's in many ways.

On 9 November 2012, Poland's Internal Security Agency arrested Brunon Kwiecien, a chemistry professor who allegedly planned to attack the Polish parliament. Kwiecien intended to construct an explosive device using four metric tonnes of ANFO inside a tanker truck, crashing through the gates of the parliament building and detonating the device within the courtyard. Had he executed his attack successfully, he likely would have caused more damage and more deaths than Breivik's explosive device (West 2012).

\section{Sources}

This study refers to the indictment, the 22 July Commission's final report, media sources and ABB's compendium. The indictment, in both Norwegian (18 pages) and English (19 pages), was electronically distributed as pdf documents to the media and includes a list of 102 persons who ABB either killed or inflicted serious physical injuries upon. For each person, the indictment includes a description of how he or she was killed/seriously injured.

The Norwegian government appointed an independent commission on 12 August 2011 to review and learn from the terrorist attacks on the Government Complex 
in Oslo and on Utøya Island on 22 July 2011. The Commission's 10 members were professionals with experience from relevant fields, and they appointed their own secretariat. The Commission submitted its report to Norwegian Prime Minister Jens Stoltenberg on Monday, 13 August 2012, and after publication, the report was made publicly available as a pdf documents on the Commission's website ${ }^{\mathrm{c}}$ in Norwegian (482 pages), as well as an extract in English (27 pages). The media coverage was used as a supplement to the Commission's report and the indictment, and was mostly obtained by conducting key word searches on the web using Google. The articles were all read through by the author.

The combination of the indictment, the 22 July Commission's final report and the media coverage make it possible to form a rather accurate picture of the incidents, whereas the correctness of ABB's compendium is more uncertain. $\mathrm{ABB}$ wrote the compendium both to convince the readers about his ideas and to advise likeminded individuals in how to help his causes. However, ABB probably also wanted to make himself look good and make his actions look more rational and purposive than they actually were. For example, ABB lied about the existence of the organization known as the Knights Templar and the purpose of his trip to Liberia. This aspect should therefore be considered when employing the compendium as a source.

\section{Results}

As stated in his compendium, it is assumed that ABB's purpose in attacking was to strike targets with a high number of (multicultural) traitors that were also rather easy to hit. ABB explicitly identifies Marxist/multicultural parties (including headquarters and annual meetings) as attractive targets (Berwick 2011, pp. 1449-1450). Moreover, he also discusses how to choose which traitor to assassinate: "The third mistake is to select an overwhelmingly protected individual as a target for assassination. Twelve failed attempts on an extremely well-protected individual could have alternatively been 12 successful attacks on lesser targets executing more than 50 primary targets. Targets should be influential media personalities - multicultural politicians, journalists/editors, cultural Marxist professors, Marxist writers/ artists, NGO leaders and global investors. Obviously, focus on individuals who do not have armed body guards" (Berwick 2011, p. 1305). He explains this further by saying: "Approximately 10-20 of our most attractive targets in a given country are likely to be under armed police guard, so choose five targets that are not likely to be selected for armed protection. The actual five targets may be any category of A or B traitors, hardened influential Marxists or multiculturalist career cynisists or suicidal humanists" (Berwick 2011, p. 1424).

\section{The explosive attack}

This section's purpose is to investigate what sort of measures might have impeded the transport of explosives in the 2011 Norway explosive attack. The first part presents the crime script $\mathrm{ABB}$ had to follow to complete a successful explosive attack. The second part outlines how $\mathrm{ABB}$ transported the explosives from the safe house at Rena to the bomb site, and points out some possible script clashes between $\mathrm{ABB}$ and other relevant actors. Third, a discussion of which measures that could have either stopped the attack or reduced the harm inflicted, and how ABB might have adapted to these measures, is included. Lastly, this section discusses whether these measures also would have impeded other comparable attacks.

\section{Crime script (1)}

A crime script for an offender when leaving a vehicleborne device could go something like this:

1. Devise outline plan:

i. Establish desired outcome (scale of death/ destruction/publicity);

ii. Establish likely target locations.

2. Perform reconnaissance without being detected:

i. of suitable area(s) for leaving a vehicle-borne device (including parking restrictions, parking enforcement, normal parking activity, physical security, closed-circuit television and any blast enhancing factors).

ii. of transport route(s) into suitable area.

iii. of escape route(s) from suitable area.

3. Decide upon the most appropriate modus operandi (probably only two main options):

i. Time delay device (long or short);

ii. Command initiation (remote or co-terminus (co-terminus $=$ suicide $)$.

4. Gather detailed information to support modus operandi:

i. from personal contact;

ii. from printed materials (books, newspapers, etc.);

iii. from the Internet;

iv. from first principles.

5. Locate suitable base from which to launch attack:

i. one's own property;

ii. a friend's property;

iii. a rented property;

iv. a derelict/ownerless property.

6. Consider personal security:

i. Counter-surveillance;

ii. Cover story;

iii. Physical protection.

7. Obtain suitable explosive materials/precursors without being hurt or detected (probably three main options): 
Either

i. purchased, or

ii. stolen, or

iii. homemade from purchased or stolen precursors.

8. Obtain information about how to assemble a device:

i. Purchase or steal necessary materials;

ii. Purchase or steal necessary tools;

iii. Assemble device.

9. Obtain vehicle and other tools for transport and containment of explosive device without being detected.

10. Transport vehicle to target without being spotted or challenged or explosives being detonated by accident.

11. Find suitable spot for the explosive(s) and (if necessary) for nearby viewing point for detonation without being spotted or challenged.

12. Remove any physical obstacles at detonation site without being spotted or challenged.

13. Arm device and leave vehicle without being spotted or challenged.

14. Leave area or go to viewing point.

15. Detonate device if command initiated (e.g. radio or telephone controlled) without being spotted or getting injured from explosion.

\section{Detailed narrative (2)}

Step 10 above, "Transport vehicle to target without being spotted or challenged or explosives being detonated by accident", describes how ABB needed to transport the vehicle with explosives safely to the target. The detailed narrative about how $\mathrm{ABB}$ implemented this step is sketched out below.

To make the transport possible $\mathrm{ABB}$ first needed to obtain a vehicle. His compendium describes how he rented a van from the AVIS Rental Company, picked it up in Oslo on 15 July and removed the car's insignia when back at the farm (his safe house) (Berwick 2011: 2346). From 18 to 19 July ABB loaded the van, including the device and anti-friction/shock stuffing. ABB had created this stuffing by cutting up a mattress and placing it in three layers in a cardboard box, and used this "to transport the booster and detonators separately from the main cargo" (Berwick 2011: 2348-2349).

On the evening of 20 July at approximately $10 \mathrm{pm}$, pictures from the toll ring show that the van passed into the Oslo city centre from the east (Helgesen 2011). ABB then parked the van outside a garden centre at Skøyen, an area in the Western part of Oslo (ABC nyheter 2012). Next, it is known that the van crossed an entry ramp into the city centre close to Skøyen at 3:04 pm on 22 July (Helgesen 2011; Blom 2011; Johansen et al. 2011). $\mathrm{ABB}$ then parked near the entrance of the government building and was observed running away at 3:17 pm
(Sandvig et al. 2011; Andersen and Grøttum 2011; Vikås et al. 2011; NOU 2012). At precisely 3:25 and 22 seconds pm, the improvised explosive device was detonated (The Public Prosecutors of Oslo 2012).

\section{Script clashes (3)}

Transport-related script clashes here include:

- Car rental company (AVIS) might provide insignia that cannot be removed versus offender making the rental car anonymous to minimize the probability of being spotted or challenged.

- Surveillance by officials along the transport route into the city centre versus offender transporting vehicle to target without being spotted or challenged

- Surveillance by place managers and passersby outside the government building versus offender parking vehicle, detonating explosives and escaping without being spotted or challenged.

\section{Situational crime prevention measures (4)}

What sort of measures could have impeded $\mathrm{ABB}$ in transporting the vehicle to the target without being spotted or challenged or explosives being detonated by accident?

One possible (extreme) measure is physically fencing off a larger area around the government building to stop anyone from bringing vehicles to the target areas. Simple fences would probably have impeded ABB, but barriers that can withstand some force would also stop vehicles using speed to force itself through the barriers. However, this measure would also stop any legitimate vehicle from entering the area, including emergency vehicles, deliveries and so on. This problem could be somewhat amended by entry points for vehicles with permits to enter, which would let emergency vehicles and vehicles with other legitimate purposes in, although at a delay. Such entry points would need to be equipped with both instruments and personnel suitable for stopping explosive attacks. If the entry points lack the capability to actually stop the attacker with equipment, the entry points will only be a warning system. Another option is to close off the area only at certain hours (for instance when the area would be more crowded). However, this timelimited ban would require security personnel to check the area for vehicles and perhaps fine anyone who has not removed their vehicle before the ban goes into effect. These adjustments could be combined, but they would both incur increased costs, as well as heightening the risk of any offender being able to smuggle explosives into the area.

A less extreme measure would be to make it impossible to park close to the government building. In fact, some bollards had been installed outside the building, 
which ensured a small standoff between the bomb and the government building.

Explosive detectors could also be installed, either at the entry points to a closed off area or at an outer perimeter such as the toll ring. An explosives detector is "a device capable of detecting the presence of certain types of explosives"(Garcia 2008, p. 331). Nevertheless, the cost and speed of the current technology makes this option less viable. The follow-up of any alarm could also make the measure too people-intensive and thus too expensive (Meyer and Ekblom 2011).

A measure that could limit the size of an explosion is to limit the size of the vehicles allowed access into an area with access control. This measure would make it more difficult to transport larger explosives into the area, but would also demand enforcement (probably access control). This measure would probably be most effective when combined with the measure of closing off a larger area, while including entry points for vehicles with permission to enter.

A last measure is to make the roads into the area bumpy, and thus make it more risky to drive across without detonating the explosives by accident. However, such bumps would also make driving much less comfortable for all drivers, and might also harm other types of deliveries.

\section{Rational planning (5)}

How would ABB have reacted if he had been denied access for his vehicles? If physical obstacles had blocked $A B B$ from transporting a vehicle into the area, he would have had five main choices of action: (1) abandon the attack entirely, (2) leave the vehicle at the perimeter as close as possible to the government building, (3) attack another target, (4) leave a (smaller) person-borne explosive inside the area, or (5) choose another attack mode. The best outcome (for the authorities) would be him abandoning the attack entirely. Leaving the vehicle at the perimeter could also be beneficial if it had caused fewer deaths and/or less material damage. The damage inflicted if the perimeter is attacked should therefore be considered before deciding its location. To move the perpetrator toward another target would only be beneficial as long as an attack on such a target would cause less harm than an attack on the government building. If more people would be killed (e.g. because more people find themselves at the new target or the building has a higher risk of collapsing), the embargo on vehicles around the government building could actually be detrimental. The authorities should therefore consider possible target substitutions and their consequences for the expected harm before introducing such a ban on vehicles. Finally, ABB might have chosen a completely different mode of attack such as a shooting massacre, which would probably have been better because such a massacre most likely would have made it impossible for ABB to go on to commit the other shooting massacre at Utøya. Prospective victims would also have more escape opportunities (more opportunities to run and hide) than at Utøya, and the authorities would probably have been able to confront him sooner. ABB could also have employed unconventional weapons that might have inflicted more harm, although unconventional weapons are either difficult to obtain, create or spread without being detected.

If the authorities allowed for some vehicle access into the closed off area, ABB could have faked permission to enter (pretending to be either an emergency vehicle or deliveries). One way of making it more difficult to choose such a deception for lone wolves is to demand that all vehicles entering the area need to have at least two occupants.

If all the space close to the government building had been fenced off, ABB could only have left the car in the street. The bomb would therefore have been further from the government building, while being closer to the building across the street. Passersby might also have reacted sooner, including those driving other vehicles. However, would $\mathrm{ABB}$ being forced to leave the car in the street made have any difference anyway? The security guards supposedly initiated investigative efforts when the car was parked outside the government building, and CCTV pictures recorded ABB walking from the car in a fake police uniform, helmet, face shield and pistol (Andersen and Grøttum 2011). Since no one succeeded in impeding the attack when both the car and ABB supposedly seemed suspicious, ABB being forced to park the car in the street would probably not have stopped the attack. A few people could have escaped, but other people might just as easily have gathered around instead. The only effect of removing parking spaces would thus have been some redistribution of the damage between buildings.

Explosive detectors at entry points or an outer perimeter might be avoided by either choosing explosives that the detectors would not detect or "hiding" them. Another way to avoid detectors is to make the explosives inside the perimeter. In the compendium, however, Breivik devotes a lot of space to the problem of avoiding detection, and he worries quite a bit about someone noticing anything strange whenever anyone drops by his rented farm (Berwick 2011). Making explosives without being detected in a highly populated area could therefore be difficult. $A B B$ could probably have easily dealt with the bumpy roads by making more anti-friction stuffing.

In summary, the most effective measure aimed at impeding $\mathrm{ABB}$ in transporting the vehicle to the target without being spotted or challenged, or explosives being 
detonated by accident, might be closing off a larger area. This measure could be combined with entry points for vehicles with permission to enter. Additionally, these entry points should be manned with qualified security personnel and, if viable technology exists, explosive detectors could be added. A size limit on vehicles could make screening easier and limit the consequences of a failure of the explosive detection.

\section{Comparable attacks (6)}

Would denying vehicle access have impeded comparable attacks?

The Oklahoma bombing On 19 April 1995, Timothy McVeigh parked a large Ryder truck with explosives outside the Alfred P. Murrah Federal Building in downtown Oklahoma City. The vehicle bomb destroyed half of the nine-story building, killing 168 and injuring several hundred people (Hartzler 1997; BBC news 1998). Would a physical barrier have stopped this attack? The Alfred P. Murrah Federal Building was located in the middle of the city centre and earlier plots have demonstrated the building's attractiveness as a right-wing target (Thomas and Smothers 1995). The Alfred P. Murrah Federal Building would hence have probably been included in any fenced off area.

How would Timothy McVeigh have adapted if he lacked vehicle access to his preferred target? He chose the Alfred P. Murrah Federal building because he was convinced it contained the Bureau of Alcohol, Tobacco and Firearms, and he considered it as an "easy target". Nonetheless, he seems to have had general anti-government sentiments, and he may have therefore perceived all federal buildings to be legitimate targets (Hartzler 1997). A Google map search on federal buildings in Oklahoma City shows five downtown- and four less centrally located federal buildings, and any closed off area would perhaps have included the downtown buildings, while excluding the four other buildings. However, satellite pictures indicate that these four buildings might be better protected and at least not as tall as the Alfred P. Murrah Federal Building. Any attack on these less centrally located buildings may therefore have caused less harm than the Alfred P. Murrah Federal Building attack. Thus, fencing off an area would have been beneficial in this attack.

The Doha players theatre bombing On 19 March 2005, an Egyptian named Omar Ahmed Abdullah Ali crashed an SUV into the lobby of the Doha Players Theatre in Doha, Qatar. Subsequently, he detonated a bomb, killing himself, the British director and injuring 12 others (Lepeska 2010; BBC news 2005b). If the show had not started earlier than the previous two days, more people would have been in the café at the time of the attack and the number of killings could have been higher (BBC News 2005a). The Doha Players Theatre was situated outside the city centre and would therefore not have been inside any perimeter protecting the city centre. However, the theatre was a well-known haunt of the expat community, and international schools in the area had increased the security owing to warnings of a heightened terrorism risk in Qatar (BBC News 2005a, 2005b). Hence, the theatre could have installed a small standoff outside of its building, and the effect of the attack would probably have been much smaller.

A lack of information on the motivation behind the attack makes it difficult to establish how Omar Ahmed Abdullah Ali would have reacted if faced with a standoff. If he targeted Westerners (as recommended by al-Qaeda's Saudi boss, Saleh al-Oufi), a standoff could have increased the relative risk of more crowded ex-pat targets in Doha, such as international schools. An attack on another target might therefore have caused more harm than the potential harm from the Doha Players Theatre attack.

The polish copycat Brunon Kwiecien allegedly planned to ram through security fences around the Polish parliament with a tanker truck loaded with an explosive device and detonate this device within the courtyard. Kwiecien considered ABB's attack on the Norwegian government building a failure; $A B B$ parked his vehicle outside the government building, putting a small distance between the explosive device and the building. Kwiecien planned to construct a larger explosive device and drive the truck into the gates to ensure destruction of the building (West 2012). Kwiecien was apparently convinced that foreigners ran Poland, and therefore the government and the President needed to die. Moreover, he had already travelled to Warsaw to carry out reconnaissance missions on the parliament building (Day 2012).

The Polish parliament building already had a security fence that Kwiecien was planning to ram. The security fence must have either been too weak to withstand the required force or Kwiecien underestimated its ability to withstand the force. If Kwiecien had underestimated the barrier's strength, the device may have detonated at the outer perimeter instead of in the courtyard. An explosion further from the parliament building would less likely have caused a structural collapse of the parliament building and might therefore have caused fewer deaths. In fact Kwiecien was right about the security fence lacking in strength so the case illustrates the need to construct barriers that can withstand substantial force.

\section{Summary}

The above sections show that the most effective way of impeding $\mathrm{ABB}$ in transporting the explosives may have 
been to fence off an area around the government building to stop vehicles from entering this area.

\section{The shooting massacre}

This section investigates what type of measures might have impeded the transport of $\mathrm{ABB}$ with weapons in the 2011 Norway shooting massacre and what type of measures would have supported the transport of victims from the shooting site. The first part presents the crime script $A B B$ had to undergo to complete a successful shooting massacre. The second part outlines how $\mathrm{ABB}$ transported himself and his equipment from the safe house at Rena to Utøya, and points out some possible script clashes between $\mathrm{ABB}$ and other relevant actors. Third, which measures could have either stopped the attack or reduced the harm inflicted, and how $A B B$ might have adapted to these measures, is discussed. Finally, this section discusses whether these measures also would have impeded other comparable attacks.

\section{Crime script (1)}

A crime script for an offender performing a shooting massacre could go something like this:

(1) Devise an outline plan:

i. Identify likely target population;

ii. Identify likely gathering places and select the most desirable.

(2) Establish preferred modus operandi:

i. Automatic weapons required?

ii. Long-range or close quarter attack (CQA)?

iii. Hostages?

iv. Options to limit movement of victims.

(3) Perform reconnaissance without being detected:

i. of suitable areas for opening fire;

ii. of transport routes into suitable area;

iii. of the likelihood of armed opposition (at the location or as a quick response);

iv. of opportunities to acquire additional weapons during attack (e.g. from surprise attack against armed police);

v. of escape routes from a suitable area if planning to escape;

vi. of opportunities for a deception plan (e.g. dress like a police officer, workman, etc.).

(4) Establish secure location from which to launch attack:

i. one's own property;

ii. a friend's property;

iii. a rented property;

iv. a derelict/ownerless property;

v. a vehicle (e.g. houseboat, camper van).

(5) Consider personal security:

i. counter-surveillance; ii. a cover story;

iii. physical protection.

(6) Obtain firearms and ammunition for the shooting incident without being hurt or detected.

Either:

i. purchase firearms and ammunition legally, or

ii. purchase firearms and ammunition on the black market, or

iii. steal firearms and ammunition.

(7) Obtain any other tools necessary for performing the shooting massacre without being detected.

(8) Perform fire training without being detected.

i. Train using shooting simulator/game, and/or

ii. Train using shooting range, and/or

iii. Train using other (hidden) areas.

(9) Travel to selected target without being spotted or challenged.

(10) Charge firearms without being challenged.

(11) Launch firearms without being challenged.

(12) Repeat charging and launching firearms until either challenged or escape.

(13) Leave area if planning to escape.

\section{Detailed narrative (2)}

ABB with tools Step 9 above, "travel to selected target without being spotted or challenged", describes how $A B B$ needed to get to Utøya unhindered. Here the detailed narrative about how ABB implemented this step is sketched out.

As early as 6 April 2011 he leased a silver grey Fiat Doblo van from AVIS. He removed all the AVIS insignias so the car would pass as his own (Berwick 2011, p. 2326).

On the evening of 21 July at approximately 11 pm, pictures from the toll ring show the Fiat passing into the Oslo city centre from the east (Helgesen 2011). As with the van with explosives, $A B B$ then parked the Fiat in Sigurd Iversens vei in Skøyen (NOU 2012, p. 17). Next, pictures show the Fiat crossing an entry ramp into the city centre close to Skøyen at approximately 11 am on 22 July (Helgesen 2011). He drove to Hammersborg Square, a short walk from the government building, and parked the Fiat there. After leaving the van with explosives outside the government building, he walked up to the Fiat at Hammersborg square (Sandvig et al. 2011) and started the drive towards Utøya. According to ABB's defence lawyer, ABB believed police roadblocks had caused the queue and ended up driving several detours to avoid these roadblocks (Johansen et al. 2011). Before 4:30 pm, he arrives at Utvika and parks his car at a parking lot near a grove (Vikås et al. 2011; VG TV 2011).

Owing to the yearly summer camp of the organization known as AUF (Workers' Youth League), 564 persons were on the island of Utøya (The Public Prosecutors of 
Oslo 2012). The summer camp had stationed a tent with guards (participants from the summer camp) at the quay to register all the people travelling back and forth to Utøya. One of the guards approached ABB and asked him about his errand. ABB informed him that he came from PST (the Police Security Service) and was supposed to do a routine security inspection at Utøya after the bomb explosion in Oslo. ABB wore a fake police uniform and, upon request, displayed a fake service certificate. The young guard was puzzled that the alleged police officer arrived in a civilian car, but supposed that all available police cars were participating in the rescue work in Oslo (NOU 2012, p. 25).

At 4:57 pm the captain of the MS Thorbjørn (the ferry between Utvika and Utøya) was notified about a police officer $(\mathrm{ABB}$ with both fake police uniform and fake police ID) who wanted to be ferried across to Utøya. At 5:04 pm the ferry left Utvika with ABB onboard (Johansen et al. 2011; Helgesen 2011; Vikås et al. 2011; VG TV 2011), and at 5:17 pm he disembarked at the Utøya pier (The Public Prosecutors of Oslo 2012; NOU 2012).

Victims Steps 10-12 above, "charging and launching firearms until either challenged or escape", describes what $\mathrm{ABB}$ needed to do to kill people when he finally arrived at Utøya.

The police have estimated that $\mathrm{ABB}$ started shooting at approximately 5:21 pm. He shot his two first victims, Monica Bøsei and Trond Berntsen, on the lawn in front of the main house (NOU 2012, p. 26), and on the way up to the "café building" he shot and killed another victim, before continuing on his 75-minute-long shooting spree around Utøya. He ended up killing 69 persons, of whom 67 were hit by fatal gunshots. The two last persons died as a result of injuries sustained in a fall, and/ or drowning while attempting to get away without having been hit by gunshots (The Public Prosecutors of Oslo 2012). At 6:25 pm, the police arrived at Utøya (Fossan 2011) and arrested him at approximately 6:35 pm (The Public Prosecutors of Oslo 2012).

Another prerequisite for $\mathrm{ABB}$ managing to commit so many killings is the victims' presence. When the youth at Utøya became aware of the shooting, they attempted to escape. At least 250 youths jumped into the sea and started swimming away (Haug and Schjønberg 2011), which was an effective escape strategy for the ones with good enough swimming abilities. At 5:40 pm, ABB came across some youths swimming away from Utøya and started shooting at them, but did not hit anyone. Only one person died from drowning when attempting to escape by swimming, while another youth died from falling off a cliff while fleeing (NOU 2012, p. 26). Many youths were picked up by boats operated by volunteers, but others had to swim all 500 metres to the mainland (Meland 2011; Gillesvik 2011). A few youths even managed to escape by swimming after being shot (Bentzrud 2011).

Some youths evacuated by boat, whereas nine used the same ferry as ABB arrived on (Meland 2011; Tilseth 2011). ABB came across one group of youths that was rowing away from Utøya and went after them and started shooting. The boat was hit by several shots, but none of the inhabitants were hurt (NOU 2012, p. 26-27). Hence, whenever possible, evacuation by boat seems to have been a good escape strategy.

The rest of the youths attempted to hide on the island, including inside or outside houses (Martinovic 2011; Stølan 2011; Mersland and Ankersen 2011), although this escape strategy did not always succeed. For example, at 5:31 pm ABB came across a group of youths hiding along a path and shot and killed 10 of them while they were lying close to each other. An 11th person was shot, but survived (NOU 2012, p. 26). Later, at the pump house, ABB surprised some youths who had been hiding for some time, telling them he came from the police, and after a short break he started shooting. The perpetrator shot and killed 14 people outside the pump house (NOU 2012, p. 27). At approximately 6:30, ABB again surprised some youths in hiding, killing five and hurting five to six people (NOU 2012, p. 27).

Hiding outside therefore seems to have been a risky escape strategy, while hiding behind a locked door was safer, with a total of 47 people escaping safely after hiding in the "Schoolhouse". ABB approached the door and shot two times through the windows in the door, but did not attempt to enter (Johnsrud 2012).

\section{Script clashes (3)}

Transport-related script clashes here include:

- Surveillance by officials and other passengers on the ferry versus the offender travelling to selected target without being spotted or challenged.

- People present at Utøya avoiding being shot (by either stopping or escaping the offender) versus offender shooting a firearm without being challenged.

- Rescuers assisting the people at Utøya in escaping versus the offender repeatedly charging and launching firearms until he was either challenged or escaped.

\section{Situational crime prevention measures and rational planning (4 and 5)}

ABB with tools What sort of measures could have impeded $\mathrm{ABB}$ in travelling to a selected target without being spotted or challenged? ABB posed as a policeman 
when requesting to be ferried across to Utøya, and did not hide the fact that he was carrying firearms (Øgår 2011). Passenger screening and/or metal detectors would therefore not have helped in avoiding this attack. If appropriate procedures for doublechecking the identity of public service personnel had existed, the guards or other personnel might have been able to refuse $A B B$ ferry access to Utøya. However, $A B B$ could bypass the ferry by getting a hold of his own boat and approaching the island in such a vessel.

Victims What type of measures could have removed the victims and thus impeded $A B B$ in charging and shooting firearms? ${ }^{\mathrm{d}}$ Providing more opportunities for hiding behind locked doors, such as in the schoolhouse, might have saved more lives. Furthermore, the probability of surviving the shooting was seemingly higher for people who chose to escape by swimming away instead of hiding in the open, and empowering people to evacuate the island more quickly would also have reduced the number of killings. Studies show that providing information with instructive evacuation messages during a fire can help shorten the overall evacuation time (Fridolf et al. 2011). Consequently, a broadcasting system that could warn the people at Utøya and encourage them to evacuate would probably have led to more people being able to evacuate the island. Speakers were actually already installed at Utøya and a system where designated people were able to broadcast such a warning could have been installed.

More vessels could also have increased the rate of evacuation, both for people who (rightly or wrongly) believed that they lacked the necessary skills to evacuate by swimming, and for people who just preferred to avoid $\mathrm{ABB}$ by hiding rather than swimming. One survivor describes how he ended up hiding in a crack in a mountain because the boat at the beach could not hold any more passengers (Wilhelmsen 2011). Additionally, flotation equipment could also have assisted people who lacked the necessary swimming skills.

But could ABB have exploited the existence of storage areas for evacuation equipment by shooting anyone approaching these areas? In the actual attack, ABB walked around the island searching for victims despite the presence of a pier with several boats, and if ABB had chosen to stay in one place, it would have been easier for people to avoid him by hiding or just swimming from other sides of the island. More than one storage area would have solved that problem.

In summary, including a broadcasting system for evacuation, as well as evacuation equipment, might have reduced the number of killings at Utøya.

\section{Comparable attacks (6)}

The cave of the patriarchs massacre On 25 February 1994 Baruch Goldstein, an Israeli settler and doctor, entered the Ibrahim Mosque (the Isaac Hall) at the Tombs of the Patriarchs during the morning prayers (Church et al. 1994). Since he managed to avoid all security cameras when entering, possibly because of knowledge gained through his position as a reserve officer, information is lacking about how he entered the mosque (Helm 1994). He may have entered through the main entrance, the door connecting the mosque and the Abraham Hall or the door from the Yosefiya Hall (Shamgar et al. 1994). He then opened fire on the crowd of 400 to 500 worshipers (Church et al. 1994; Hedges 1994). According to the army, Goldstein fired approximately 110 bullets in 90 seconds with his assault rifle (Hedges 1994; Haberman 1994). Goldstein killed 29 worshipers and injured 125 before the survivors managed to overpower and kill him (Issacharoff and Levinson 2010). Shocked worshipers, some wounded and others carrying dead bodies, poured out from the mosque into the passageway beyond the main entrance door. In the confusion, some soldiers in the passageway started firing, and conflicting reports on whether these shots killed anyone still exist (Hedges 1994; Haberman 1994).

Even if information about how Goldstein entered the mosque is lacking, several of the soldiers guarding the tombs have admitted to having seen him walking around with an automatic rifle at the site earlier in the morning. Nobody interfered since Jewish settlers were allowed to bring firearms when praying (in the Abraham Hall), and the soldiers apparently found no reason to check the bag where his ammunition magazines might have been (Haberman 1994). A ban on weapons at the tombs and better entry control could thus have made it much more difficult to commit the attack.

How could Goldstein have adapted if faced with such measures? He could have chosen another site inside the tombs for the shooting, and he would then probably have increased the risk of either being shot by soldiers at the site during the shooting and/or hurting other Jews frequenting the Tomb. He could also have chosen another site outside the Tomb, but no other site in Hebron has the same symbolic value for both the Muslims and the Jews; the Tombs of the Patriarchs is actually the second holiest place among all Jewish holy sites. He might therefore have abandoned the attack entirely if he did not expect to be able to commit a shooting massacre in the Abraham Hall.

Better evacuation opportunities could have also helped to remove some of the victims. However, since the Tombs of the Patriarchs are a holy shrine and a listed historical area, evacuation routes are difficult to add. As a result, better evacuation opportunities might not have 
had such a large effect owing to the short duration of the incident. However, teaching soldiers how to better deal with a panicking crowd would probably have been effective, and lives might have been saved if none of the soldiers had started shooting at the crowd.

The fort hood shooting On 5 November 2009 Nidal Malik Hasan, a U.S. Army Major, entered the Soldier Readiness Processing Center (a medical processing centre for soldiers returning from- or about to be sent overseas) at Fort Hood armed with two non-military issue pistols, including a semi-automatic. At $1 \mathrm{pm}$, Hasan was seen sitting among other soldiers getting medical examinations, and then at 1:30 pm, Hasan jumped up on a desk, shouted "Allahu Akbar" ("God is Great") and started shooting at the soldiers, stopping only to reload his weapon. Over a 10-minute-period, he killed 12 soldiers and one civilian and injured approximately 30 others (NYTimes.com 2011; BBC News 2009b; Gruen 2010; Ninan and Press 2009; Krauss 2010; BBC News 2009a). After a few minutes Hasan went outside and continued on his shooting spree. Two civilian police officers, Sergeants Mark Todd and Kimberly Munley, responded to the scene and Sergeant Mark Todd succeeded in shooting and disabling Hasan (Gruen 2010).

Hasan worked as a psychiatrist at the Darnell Medical Center at Fort Hood (Sherwell and Allen 2009), so he could therefore easily pretend to have legitimate reasons for entering the centre. Entry control without weapon screening would therefore have limited use in preventing this shooting massacre. However, if he had been searched for weapons, the non-military pistols would have been discovered and the legitimacy of him bringing these weapons to the centre could have been questioned.

How could Hasan have adapted if faced with such measures? As mentioned above, soldiers about to be sent overseas need to visit the Soldier Readiness Processing Center. Hasan, who has expressed violent Islamic extremist views, could thus have regarded this site as being particularly symbolically significant. Still, Fort Hood consists of many sites with numerous soldiers expecting to go overseas sometime; for this reason, Hasan could probably have found alternative sites suitable for a shooting massacre, while introducing entry control with a weapon search at all these sites would probably be very expensive.

The Soldier Readiness Processing Center was situated in a low, brick building with only two exits, the main entrance and a back door (Shaughnessy 2009). Pictures of the building also indicate a lack of windows to evacuate by (Tolbert 2009), though if more evacuation opportunities had existed, more people might have escaped and more lives could have been saved. In the middle of the shooting Hasan exited the building, searching for more victims, while a serviceman stationed at Fort Hood has said that he heard the emergency announcement over the speakers outside and saw people rushing indoors (BBC News 2009a). As a result, emergency routines at the base probably saved lives that afternoon.

\section{Summary}

The section above demonstrates that stricter entry control may have impeded all of the above-mentioned attacks. Measures facilitating evacuation could have (and actually did) help in two out of three attacks, the ABB and Fort Hood attacks. Very brief shooting massacres, such as the Goldstein attack, might not last long enough to enable any meaningful evacuation, and measures facilitating evacuation are therefore not as effective in these cases.

\section{Discussion}

This study's aim was to determine what type of transport-related measures might impede lone-wolf attackers, either by stopping an attack entirely or just reducing the harm inflicted. This paper has combined crime scripts, situational crime prevention and rational planning to investigate what sort of measures might have impeded the transport in the 2011 Norway attacks, in addition to discussing whether these measures also would have impeded other comparable attacks.

This study has shown that denying vehicle entrance to an area can be very effective in impeding vehicle-borne explosive attacks. To give access to vehicles with key functions, such as emergency vehicles and deliveries, the authorities could add entry points for vehicles with special permissions, thereby easing the ban in less crowded hours. The authorities could also demand that all vehicles entering should have at least two occupants to make it more difficult for lone attackers to sneak a vehicle bomb into the area by obtaining false permission. If the technology is/becomes viable, the authorities could install explosive detectors at the entry points.

Nevertheless, the authorities should consider where to put the perimeter and, in particular, any entry point owing to a heightened risk at the barrier. The authorities should also bear in mind that stopping vehicle access to the terrorists' most preferred targets may cause the terrorists to attack other targets that are more accessible. If an attack on these more accessible targets would cause more harm (more killings etc.), closing off access to the most attractive targets could actually increase the expected harm of explosive attacks.

Entry control focusing on checking identity, the visit's purpose and searching for firearms could have impeded all of the above (lone-wolf) attackers when launching shooting massacres, although the type of entry control needed varies. In the $\mathrm{ABB}$ and Goldstein, attacks the 
offenders were visibly armed, while Hasan hid his firearms when entering. In both the $\mathrm{ABB}$ attack and the Fort Hood attack, the offenders successfully pretended to have legitimate reasons to be at the site. Goldstein, however, had no legitimate reason to enter the Muslim prayer hall.

Entry control is people-intensive and can thus be very expensive. Hence, such measures should be applied only at the targets that the terrorists find most attractive and/ or when it may be introduced at a small cost. Using people already at the site, such as the people managing the Utøya ferry, is a very cheap way of increasing entry control.

Measures facilitating evacuation can also reduce the harm of a prolonged attack. Such measures also reduce the harm of other unwanted incidents, such as fires, but can sometimes be difficult to install in existing buildings, especially when the buildings have historical value.

This study suffers from some limitations. First, the analysis uses a few lone-wolf attacks to derive some general policy recommendations that could increase costs and other inconveniences for ordinary people visiting such targets. Given that the probability of an attack towards any specific target at a specific time is very small, one may question whether such security benefits actually outweigh the costs. This dilemma is a key tension in counter-terrorism, and the leap from scientific findings to policy is therefore immense. Given our inability to predict low probability events, a policy maker cannot make his or her decision based only on such scientific findings; the policy maker must also consider what costs society is actually willing to incur to reduce risk.

This study is also limited by the fact that it draws only on secondary sources, although given the nature of research in the field of counter terrorism this is for now inevitable.

\section{Endnotes}

${ }^{a}$ From Klungtveit (2011) (author's translation).

${ }^{\mathrm{b}}$ An assassination is a targeted murder of a prominent person or political figure by a surprise attack.

${ }^{\mathrm{c}} \mathrm{See}$ http://www.regjeringen.no/smk/html/22julikommisjonen/22JULIKOMMISJONEN_NO/EN.HTM

${ }^{\mathrm{d}}$ More armed guards at Utøya and a faster response from the authorities might, of course, also have impeded $\mathrm{ABB}$ in shooting, but this is outside this paper's scope.

\section{Competing interests}

The author declares that she has no competing interests.

\section{Acknowledgments}

I have received valuable comments and advice from Cato Hemmingby and Jacob Aasland Ravndal. I thank Institute of Transport Economics, Norway, for funding this study. I also thank Adrian Dwyer for valuable comments on the crime scripts.
Received: 25 February 2013 Accepted: 25 November 2013

Published: 1 December 2013

\section{References}

ABC nyheter. (2012). http://www.abcnyheter.no/nyheter/2012/04/19/1904-2012. Accessed 20.04.2012 2012

Andersen, MA, \& Grøttum, E-T. (2011). Her løper Breivik vekk fra bombebilen. http://www.vg.no/nyheter/innenriks/22-juli/artikkel.php?artid=10010247. Accessed 3 October 2011.

BBC News. (1998). History of attacks on US personnel. http://news.bbc.co.uk/2/hi/ americas/147237.stm. Accessed 7 October 2011.

BBC News. (2005a). 'It was absolute chaos'. http://news.bbc.co.uk/2/hi/ middle_east/4365643.stm. Accessed 7 October 2011.

BBC News. (2005b). Protest rally over Qatar bombing. http://news.bbc.co.uk/2/hi/ middle_east/4368267.stm. Accessed 7 October 2011.

BBC News. (2009a). Deadly shootings at US army base. http://news.bbc.co.uk/2/hi/ 8345713.stm. Accessed 28 October 2011.

BBC News. (2009b). Timeline: fort hood shootings. http://news.bbc.co.uk/2/hi/ americas/8346315.stm. Accessed 28 October 2011.

Belli, R, \& Freilich, JD. (2009). Situational crime prevention and Non-violent terrorism: a "soft" approach against ideologically motivated Tax refusal. In JD Freilich \& GR Newman (Eds.), Reducing terrorism through situational crime prevention (Vol. 25, pp. 173-206, Crime prevention studies). Monsey: Crime Justice Press.

Bentzrud, C. (2011). Emma svømte med 11-åring: "Jeg trodde politimenn var snille». http://www.tv2.no/nyheter/innenriks/emma-svoemte-med-11aaring-jegtrodde-politimenn-var-snille-3546210.html. Accessed 17 October 2011.

Berwick, A. (2011). Anders Behring Breivik. London, Oslo: 2083 A European Declaration of Independence.

Blom, HP. (2011). Derfor tok anders Behring Breivik omveier til Utøya. http://www. nrk.no/nyheter/1.7748599. Accessed 7 September 2011.

Borum, R. (2013). Informing lone-offender investigations. Criminology \& Public Policy, 12(1), 103-112. 10.1111/1745-9133.12016.

Church, GR, Beyer, L, Hamad, J, Fischer, D, \& McAallister, JFO. (1994). When fury rules. Time. Retrieved from: http://www.time.com/time/magazine/article/ 0,9171,980291-1,00.html.

Clarke, RV. (1983). Situational crime prevention: its theoretical basis and practical scope. Crime and Justice, 4, 225-256.

Clarke, RV, \& Newman, GR. (2006). Outsmarting the terrorists. Westport: Praeger Security International.

Cornish, DB. (1994). The procedural analysis of offending and its relevance for situational prevention. In RV Clarke (Ed.), Crime prevention studies. New York: Criminal Justice Press.

Day, M. (2012). Polish bomb plotter said 'Breivik made mistake,' The Telegraph. Chatham: Telegraph Media Group. Retrieved from http://www.telegraph.co. uk/news/worldnews/europe/poland/9691246/Polish-bomb-plotter-saidBreivik-made-mistake.html.

Ekblom, P. (2011). Crime prevention, security and community safety using the 5/s framework (crime prevention and security management). Basingstoke: Palgrave Macmillian.

Fattah, G. (2007). Nichols says bombing was FBI op. http://law2.umkc.edu/faculty/ projects/ftrials/mcveigh/conspirators.html. Accessed 25 October 2011.

Fossan, EW. (2011). Dette er gjerningsmannens antatte rute. Aftenposten: Aftenposten.no

Freilich, JD, \& Chermak, SM. (2009). Preventing Deadly Encounters between Law Enforcement and American Far-Rightists. In JD Freilich \& GR Newman (Eds.) Reducing terrorism through situational crime prevention (vol. 25, pp. 141-172, crime prevention studies). Monsey: Crime Justice Press.

Freilich, JD, \& Newman, GR (Eds.). (2009). Reducing terrorism through situational crime prevention (crime prevention studies). Cullompton: Willan.

Fridolf, K, Nilsson, D, \& Frantzich, H. (2011). Fire evacuation in underground transportation systems: a review of accidents and empirical research. Fire Technology. DOl: 10.1007/s10694-011-0217-x.

Garcia, ML. (2008). The design and evaluation of physical protection systems. Boston: Butterworth-Heinemann.

George, AL, \& Bennett, A. (2005). Case studies and theory development in the social sciences (BCSIA studies in international security). Cambridge: MIT Press.

Gillesvik, K. (2011). De trodde vi ville skade dem, Vårt Land. Oslo: Mentor Medier. Retrieved from http://www.vl.no/samfunn/-de-trodde-vi-ville-skade-dem/. Gruen, M. (2010). The massacre at fort hood Target: America (Vol. 24). New York, NY: The NEFA Foundation. 
Gruenewald, J, Chermak, S, \& Freilich, JD. (2013). Distinguishing "loner" attacks from other domestic extremist violence. Criminology \& Public Policy, 12(1), 65-91. 10.1111/1745-9133.12008.

Haberman, C. (1994). Confusing israeli testimony poses possibility of hebron accomplice. http://www.nytimes.com/1994/03/18/world/confusing-israelitestimony-poses-possibility-of-hebron-accomplice.html?src $=\mathrm{pm}$. Accessed 3 November 2011.

Hartzler, PJ. (1997). Opening statement. http://law2.umkc.edu/faculty/projects/ ftrials/mcveigh/prosecutionopen.html. Accessed 7 October 2011.

Haug, CS, \& Schjønberg, S. (2011). Vi ble bedt om å komme oss unna mens vi berga 250 ungdommer. http://www.dagbladet.no/2011/07/24/nyheter/utoya/ massemord/17439479/. Accessed 23 November 2012.

Hedges, C. (1994). That day in hebron - a special report.; soldier fired at crowd, survivors of massacre say. http://www.nytimes.com/1994/03/16/world/that-dayhebron-special-report-soldier-fired-crowd-survivors-massacre-say.html?srcc = pm. Accessed 27 October 2011.

Helgesen, OK. (2011). Bombebilen sto i Oslo i to dager før bomben smalt. http:// www.tu.no/nyheter/article289171.ece. Accessed 8 September 2011.

Helm, S. (1994). Jewish killer attacked mosque last year: evidence is mounting that baruch goldstein was known to be dangerous well before the massacre, writes sarah helm. http://www.independent.co.uk/news/world/jewish-killer-attackedmosque-last-year-evidence-is-mounting-that-baruch-goldstein-was-known-tobe-dangerous-well-before-the-massacre-writes-sarah-helm-1426229.html. Accessed 27 October 2011.

Issacharoff, A, \& Levinson, C. (2010). Settlers remember gunman Goldstein; Hebron riots continue. http://www.haaretz.com/print-edition/news/settlers-remembergunman-goldstein-hebron-riots-continue-1.263834. Accessed 20 October 2011.

Johansen, PA, Mjaaland, O, \& Sandvig, J. (2011). Trodde ulykke var politisperring. http://www.aftenposten.no/nyheter/iriks/article4198458.ece. Accessed 8 September 2011.

Johnsrud, N. (2012). Ville drepe terroristen Retrieved 30 November, 2012. Oslo: Stiftelsen Dagsavisen. Dagsavisen.

Klungtveit, HS. (2011). Selv ikke Stasi-Tyskland kunne ha stoppet denne mannen. http://www.dagbladet.no/2011/07/25/nyheter/innenriks/terror/massedrap/ anders_behring_breivik/17451571/. Accessed 5 August 2011.

Krauss, C. (2010). Witnesses recount horror at Ft. Hood. http://www.nytimes.com/ 2010/10/14/us/14hearing.html. Accessed 28 October 2011.

Lepeska, D. (2010). Five years after terror, Doha players play on. In D Lepeska (Ed.), To Clash or not to Clash (Vol. 2011): Google. Retrieved from http://queondaguero.blogspot.com/2010/03/five-years-after-terror-dohaplayers.html.

Martinovic, E. (2011). Helvette på Utøya. In E Martinovic (Ed.), (Vol. 2011). Retrieved from http://utoyahelvette.blogg.no.

Meland, R. (2011). Flyktet i AUF-fergen. http://www.nettavisen.no/nyheter/ article3199182.ece. Accessed 17 October 2011.

Mersland, F, \& Ankersen, R. (2011). Trodde vi var eneste overlevende. http://www. fvn.no/lokalt/kristiansand/article885595.ece. Accessed 20 October 2011.

Meyer, S. (2011). Reducing harm from explosive attacks against railways. Security Journal. http://dx.doi.org/10.1057/sj.2011.23.

Meyer, S, \& Ekblom, P. (2011). Specifying the explosion-resistant railway carriage-a 'bench' test of the Security Function Framework. Journal of Transportation Security, 1-17. 10.1007/s12198-011-0082-3.

Nesser, P. (2012). Individual jihadist operations in Europe: patterns and challenges. CTC Sentinel, 5(1), 15-18.

Ninan, R, \& Press, TA. (2009). Witnesses to fort hood shootings tell tales of horror, heroism. http://www.foxnews.com/us/2009/11/07/witnesses-fort-hoodshootings-tell-tales-horror-heroism/\#ixzz1c5TzO3Uf. Accessed 28 October 2011.

NOU. (2012). Rapport fra 22. juli-kommisjonen. In Informasjonsenheten (Ed.), (Vol. 12). Oslo: Departementenes servicesenter.

NYTimes.com. (2011). Nidal Malik Hasan. http://topics.nytimes.com/top/reference/ timestopics/people/h/nidal_malik_hasan/index.html?inline = nyt-per. Accessed 25 October 2011.

Øgår, S. (2011). Han virket veldig klar og veldig fokusert. http://www.vg.no/nyheter/ innenriks/22-juli/artikkel.php?artid=10080849. Accessed 19 October 2011.

Phillips, PJ. (2009). Applying modern portfolio theory to the analysis of terrorism. Computing the set of attack method combinations from which the rational terrorist group will choose in order to maximise injuries and fatalities. Defence and Peace Economics, 20(3), 193-213. 10.1080/10242690801923124.

Phillips, PJ. (2011). Lone Wolf Terrorism. Peace Economics, Peace Science and Public Policy, 17(1), 1-29.
Phillips, PJ, \& Pohl, G. (2012). Economic profiling of the lone wolf terrorist: can economics provide behavioral investigative advice? Journal of Applied Security Research, 7(2), 151-177.

Sandvig, J, Uhlving, HH, Mjaaland, O, \& Sætervoll, L. (2011). Derfor ble han forsinket 22. juli, Aftenposten (pp. 6-7). Oslo: Schibsted.

Shamgar, M, Goldberg, E, Zouabi, AER, Yaari, M, \& Levy, M. (1994). Commision of inquiry into the massacre at the tomb of the patriarchs in Hebron. Excerpts from the report. http://www.mfa.gov.il/MFA/Government/Law/Legal\%20lssues \%20and\%20Rulings/COMMISSION\%200F\%20INQUIRY-\%20MASSACRE\%20AT \%20THE\%20TOMB\%200F\%20THE. Accessed 27 October 2011.

Shaughnessy, L. (2009). Inside fort hood center, where horror unfolded. http:// edition.cnn.com/2009/US/11/06/inside.fort.hood/index.html?iref=allsearch. Accessed 3 November 2011

Sherwell, P, \& Allen, N. (2009). Fort hood shooting: inside story of how massacre on military base happened. http://www.telegraph.co.uk/news/worldnews/ northamerica/usa/6521578/Fort-Hood-shooting-inside-story-of-howmassacre-on-military-base-happened.html. Accessed 4 November 2011.

Spaaji, R. (2012). Understanding lone wolf terrorism. Global patterns, motivations and prevention (SpringerBriefs in criminology). Dordrecht: Springer.

Stølan, J. (2011). Jorid (20) tilbake på Utøya: - Her gjemte jeg meg. http://www.vg. no/nyheter/innenriks/22-juli/artikkel.php?artid=10039607. Accessed 18 October 2011.

The Public Prosecutors of Oslo. (2012). Indictment. Oslo: Oslo Public Prosecutors.

Thomas, J, \& Smothers, R. (1995). Oklahoma City building was target of plot as early as '83, official says. http://www.nytimes.com/1995/05/20/us/oklahomacity-building-was-target-of-plot-as-early-as-83-official-says.html?pagewanted = all\&src = pm. Accessed 7 October 2011.

Tilseth, TO. (2011). Beskutt av Breivik mens hun flyktet i båt. http://www.bt.no/ nyheter/innenriks/Beskutt-av-Breivik-mens-hunflyktet-i-bt-2544790.html. Accessed 20 October 2011.

Tolbert, P. (2009). 12 Killed in fort hood shooting spree. http://www.kxxv.com/story/ 11451553/12-killed-in-fort-hood-shooting-spree. Accessed 4 November 2011.

VG TV. (2011). Slik var Breiviks fluktrute. Oslo: Mediehuset VG. Retrieved from http://www.vgtv.no/\#!/video/43921/slik-var-breiviks-fluktrute.

Vikås, M, Hopperstad, M, Ravndal, D, Nygaard, F, Brenna, J, \& Andersen, G. (2011). Her er Behring Breiviks fluktrute. http://www.vg.no/nyheter/innenriks/22-juli/ artikkel.php?artid=10010468. Accessed 13 October 2011.

West, B. (2012). Mimicking Breivik in Poland. http://www.stratfor.com/weekly/ mimicking-breivik-poland. Accessed 14 July 2013.

Wilhelmsen, T. (2011). Herman (18) snakket med massemorderen. http://tb. no/nyheter/herman-18-snakket-med-massemorderen-1.6382818. Accessed 20 October 2011.

Yun, M. (2009). An application of situational crime prevention to terrorist hostage taking and kidnapping: a case study of 23 Korean hostages in afghanistan. In JD Freilich \& GR Newman (Eds.), Reducing terrorism through situational crime prevention (Vol. 25, pp. 111-139). Monsey: Crime Justice Press.

doi:10.1186/2193-7680-2-7

Cite this article as: Meyer: Impeding lone-wolf attacks: lessons derived from the 2011 Norway attacks. Crime Science 2013 2:7.

\section{Submit your manuscript to a SpringerOpen ${ }^{\circ}$ journal and benefit from:}

- Convenient online submission

$\checkmark$ Rigorous peer review

- Immediate publication on acceptance

- Open access: articles freely available online

- High visibility within the field

- Retaining the copyright to your article

Submit your next manuscript at springeropen.com 